\title{
EFFECT OF THE CONSTRUCTIVIST INSTRUCTION APPROACH ON ACHIEVEMENT AND RETENTION OF BUILDING TECHNOLOGY STUDENTS IN TECHNICAL COLLEGES IN NIGER STATE
}

\section{UMAR, B. KUDU}

\begin{abstract}
This study was designed to determine the effects of the constructivist instructional approach on achievement and retention of Building Technology students in Technical Colleges of Niger State. A pre-test, post-test, non-equivalent control group, quasiexperimental research design was adopted. 50 students constituted the subjects in the experimental group and 50 students constituted the subjects in the control group for the study. A total of 100 students were involved in the study. Three research questions which include a null hypothesis, tested at 0.05 level of significance, guided the study. The instruments were subject to validation by experts in Industrial and technology education department and Basic Technology. The reliability coefficient obtained was 0.72 . Mean was used to answer the research questions; while T-test was employed to lest the hypothesis. The study revealed that students taught Building Technology using the constructivist instructional approach had a higher mean score than students taught using the conventional teaching method in cognitive achievement test, psychomotor achievement Test. In each of the cases, the high mean scores were found to be significant. Furthermore, the mean score of boys taught Building Technology using the constructivist instructional approach was higher than the mean score of girls taught using the same constructivist instructional approach in the cognitive achievement test.The researcher recommended that the National Board for Technical Education (NBTE) should consider a review of building technology curriculum for Technical Colleges with a view to incorporating the constructivist instructional approach into the teaching of Building Technology.
\end{abstract}

\section{Introduction}

Building technology involves the application of scientific knowledge in the design, selection of materials, construction, operation and maintenance of building technology. Building is one of the construction trades (Federal Ministry of Education (FME), 2001) offered as building construction work in Nigeria Technical colleges.

A national curriculum is adopted in all the Technical Colleges accredited by National Board for Technical Education (NBTE). The programmes in Technical Colleges are offered at two levels leading to the award of National Technical Certificate (NTC) and Advanced National Technical Certificate (ANTC) for craftsmen and master craftsmen respectively (FME. 2000). The curriculum for building technology in the Technical Colleges is developed to offer a complete secondary education in general education subject in addition to occupational area. Avvolua-efebo (2002) pointed out that the main feature of the curricular activities for technical colleges is structured in foundation and trade modules; the curriculum for each trade Consists of general education, theory and related courses, workshop practice, industrial training component and small business management and entrepreneurial training. 
The challenge for preparing students for the 21 century, workplace basic skills therefore has necessitated a shift from instructional approaches based on the behavioral learning theories to those rooted in cognitive psychological learning theories for which constructivist instructional techniques is one (Avvolua-efebo, 2002). Constructivist according to Epstein and Ryan (2002) is based on the concept that leaming is a constructive process in which the learner is building an internal illustration of knowledge on a personal interpretation of experience. Constructivist is a theory of learning based on the idea that knowledge is constructed by the learner based on mental activity. Two important notions orbit around the simple idea of constructed knowledge Demmert (2001). However explained that the first notion is that learners construct new understandings using what they already know. The second is that learning is active rather than passive. Learners apply their understanding in the light of what they encounter in new situations. If what learners encounter is inconsistent with their current understanding, their understanding can change to accommodate new experience. Learners remain active throughout this process; they apply current understandings, note relevant elements in new learning experiences, judge the consistency of prior and emerging knowledge, and based on that judgment, they can modify knowledge.

Constructivist is, therefore, a model of instruction and learning, and interactive process in social settings; it is problem solving oriented, allow students to explore and work in groups, making meaning of task and setting out to solving problems that are perplexing to them. Constructivist instructional techniques facilitate learning in the classroom.

Constructivist instructional techniques are to improve students' thinking skills and problem solving abilities. In a nutshell, the constructivist instructional approach is defined in this study, as an eclectic approach to teaching which involved the use of thinking skills, oral discourse, authentic/situated learning, collaborative work and framing instructional strategies combined during the class lesson as appropriate to suit the content of the lesson in such a way that made the students construct their own knowledge and accomplish their learning tasks based on Jerome Brunner's three principles that guide the development of instruction in a constructivist classroom listed in Cleminson (2000). These are: instruction must be concerned with experiences and contexts that make students willing and able to learn (readiness); instruction must be structured so that the students can easily grasp it (spiral organization) and; instruction should be designed to facilitate extrapolation and/or fill in the gap (going beyond information given). Based on these principles, the constructivist instructional approach is expected to enhance the learning of building technology students in Technical Colleges.

Over the years, teaching methods based on behavioural learning theory has been adopted to teach vocational subjects in the Technical Colleges irrespective of the fact that technological advancement in industry requires that students be equipped with workplace basic skills such as thinking skills, problem solving and collaborative work skills which will make them adaptable to changes in work places. According to Rojevvski (2002) lecture and demonstration methods which are based on behavioural learning theory are the main teaching/learning methods employed for implementing the curriculum in the technical colleges. Apart from the fact that these methods are teacher-centred students are not given enough opportunities to participate in the classroom instruction. These methods which are predominantly used in teaching building technology in the Technical Colleges emphasize knowledge transmission from the teacher to passive students and encourage rote memorization of fact (Boyle, Duffy \& Dimkavy, 2003). Besides, teaching methods 
which are based on behavioural learning theories are directed towards isolating the learner from social interaction and towards seeing education as a one-on-one relationship between the learner and the objective material being learned (Epistein \& Ryan 2002). The consequence of the use of these methods in teaching vocational subjects such as building technology in Technical Colleges is that students are unable to retain their learning and apply it in new situations. Rusbult (2005) indicated that traditional teaching- learning approaches based on behavioural learning theory do not adequately equip students with higher-order thinking skills, collaborative and problem solving skills, but constructivist theory does, Perhaps, if thinking skills, oral discourse, authentic/situated learning, collaborative work and framing instructional techniques are combined during instruction to teach building technology in the Technical Colleges, it will assist in developing students' thinking skills and problem solving abilities which in turn may help them improve their learning methods employed by teachers in the Technical Colleges thus, seem inadequate for equipping the students studying building technology with the work place basic skills required for work in the building industries which is vast changing with technological advancements. This raises the questions as to whether beside the teachercentered method there is no such teaching technique of the constructivist instructional approach which can influence this ugly trend in the subject.

\section{Purpose of the Study}

1. Determine the cognitive achievement scores of students taught building technology with the constructivist instructional approach and those taught using the conventional teaching methods.

2. Determine the psychomotor achievement scores of students taught building technology with the constructivist instructional approach and those taught using the conventional teaching methods.

3. Compare the cognitive achievement scores of boys and girls taught building technology using the constructivist instructional approach

\section{Significance of the Study}

The findings of the experiment on effects of the constructivist instructional approach on achievement of learning of building technology students in this study, upon dissemination will be of immense benefit to students of building technology and other vocational subjects in the Technical Colleges.

\section{Research Questions}

1. What are the mean cognitive achievement scores of students taught with the constructivist instructional approach and those taught using the conventional teaching methods?

2. What are the mean psychomotor achievement scores of students taught building technology with the constructivist instructional approach and those taught using the conventional teaching methods? 


\section{Hypothesis}

$\mathrm{H}_{01}$ : There is no significant difference between the mean cognitive achievement scores of students taught building technology with the constructivist instructional approach and those taught using conventional teaching methods.

\section{Methodology}

A quasi-experimental design was used for this study. This study was conducted in Niger State. Niger state has some distribution of industries such as Building work industries which need the services of well-trained craftsmen produced in Technical Colleges in Niger State. The population for this study comprised all 50 second year students of Building Technology in all the seven Technical colleges in Niger State. The data was obtained for 2010/2011 session from the register in the principal's office of each of the Technical College.The teachers that teach each of the two groups subjected the students to pretesting before treatment. In the pre-test the Cognitive Achievement Test (CAT) and Psychomotor Achievement Test (PAT) was administered on the students. Answer scripts will be provided for the students to fill in the correct answers for CAT while the teachers used the scoring guide of PAT for scoring the psychomotor achievement of the students. The researcher marks the answer scripts of the CAT to obtain the students' scores on cognitive achievement before the treatment. These provide baseline data on each of the dependent variables (cognitive and psychomotor Achievement of the students) before the treatment.After the two weeks, the same CAT was re-administered (as test of learning) on the students by respective teachers that taught each of the experimental and control groups. Answer scripts were provided for the students to fill in the correct answer for CAT.

The data collected from the pre-test and post-test of learning was analyzed using mean to answer the research questions. The pre-test, - post-test mean of each group (Control and Experimental groups) were compared to determine the group that performed better to answer research questions 1-3. The null hypothesis was tested using Analysis of Covariance (ANCOVA) at 0.05 level of significance.

\section{Research Question 1}

What are the mean cognitive achievement scores of students taught Building technology with constructivist instructional approach and those taught using the conventional teaching methods. This research question was answered and presented in table 1.

Table 1: Mean of pre-test and post-test scores of Experimental and Control groups in the cognitive achievement test.

\begin{tabular}{c|c|c|c|c}
\hline \multirow{2}{*}{ Group } & $\mathrm{N}$ & Pre-test & Post-test & Mean Gain \\
\cline { 3 - 5 } & & $\overline{\mathrm{X}}$ & $\overline{\mathrm{X}}$ & \\
\hline \multirow{2}{*}{$\begin{array}{l}\text { Experimental } \\
\text { Control }\end{array}$} & 182 & 3.85 & 35.60 & 31.75 \\
& 158 & 3.77 & 19.71 & 15.94 \\
\hline
\end{tabular}


The data presented in table 1 shows that the experimental group had a mean score of 3.85 in the pre-test and a mean score of 35.60 in the post-test making a pre-test, post-test gain in experimental group to be 31.75 . The control group had a mean score of 3.77 in the pre-test and a post-test mean of 119.71 with a pre-test, post test gain of 15.94 . With this result, the students in the experimental group performed better in the cognitive achievement test than the students in the control group.

\section{Research Question 2}

What are the mean psychomotor achievement scores of students taught Building technology with constructivist instructional approach and those taught using the conventional teaching methods?

This research question was answered and presented in table 2 .

Table 2: Mean of Pre-Test and Post-Test Scores of Experimental and Control Groups in the Psychomotor achievement test.

\begin{tabular}{c|c|c|c|c}
\hline Group & \multirow{2}{*}{} & Pre-test & Post-test & Mean Gain \\
\cline { 3 - 5 } & & $\overline{\mathrm{X}}$ & $\overline{\mathrm{X}}$ & \\
\hline Experimental & 182 & 2.92 & 45.84 & 42.92 \\
Control " & 158 & 2.94 & 24.00 & 21.06 \\
\hline
\end{tabular}

The data presented in table 2 shows that students in experimental group had a mean score of 2.92 in the pre-test and mean score of 45.84 in the post test. This shows a pre-test, post-test gain of 42.92. Also, the control group had a mean score of 2.94 in the pre-test and had a mean score of 24.00 in the post test giving a pre test, post test gain of 21.06 . Therefore, this result indicates that students in the experimental group performed better that the students in the control group in psychomotor achievement test.

\section{Research Question 3}

What are the mean cognitive achievement scores of boys and girls taught Building technology with the constructivist instructional approach?

This research question was answered and presented in table 3. 
Table 3: Mean of Pre-Test and Post-Test Scores of Boys and Girls Taught Building Technology with the Constructivist instructional approach achievement

Mean of Boys and Girls Taught Building Technology with the Constructivist instructional approach in the cognitive achievement Post-Test and test of learning.

\begin{tabular}{l|c|c|c}
\hline \multirow{2}{*}{ Group } & \multirow{N}{*}{$\mathrm{N}$} & Pre-test & Test for Learning \\
\cline { 3 - 4 } & & $\overline{\mathrm{X}}$ & \\
\hline Male & 112 & 35.67 & 34.33 \\
Female & 70 & 35.48 & 34.98 \\
\hline
\end{tabular}

The data presentation above shows that boys had a mean score of 35.67 in the post-test and mean score of 34.33 in the test for learning. The girls also had a mean score of 35.48 in post-test and a mean score of 34.98 in the test for learning. The girls also had a mean score of 35.48 in post test and a mean score of 34.98 in the test for academic achievement. The result indicates that the girls performed better then male students in the test for achievement of learning.

\section{Hypothesis}

$\mathrm{HO}_{1}$; There is no significant difference between the mean cognitive achievement scores of students taught Building technology with the constructivist instructional approach and those taught using conventional teaching methods.

This hypothesis was tested and presented in table 4.

Table 4: Summary of Analysis of Covariance (ANCOVA) for Test of Significance between the Mean Scores of Experimental and Control Groups in Cognitive Achievement Test

\begin{tabular}{llllll}
\hline \multicolumn{1}{c}{$\begin{array}{c}\text { Source of } \\
\text { Variation }\end{array}$} & \multicolumn{1}{c}{$\begin{array}{l}\text { Sum of } \\
\text { Squares }\end{array}$} & DF & Mean Square & F & Sig of F \\
\hline Covariates & 13.790 & 1 & 13.790 & 1.566 & .212 \\
Pre-test & 13.790 & 1 & $13.790^{\prime \prime}$ & 1.566 & .212 \\
Main Effects & 21366.499 & 1 & 21366.499 & 2426.121 & .000 \\
Group & 21366.499 & 1 & 21366.499 & 2426.121 & $.000^{*}$ \\
Explained & 21366.546 & 2 & 10683.273 & 1213.063 & .000 \\
Residual & 2967.910 & 337 & 8.807 & & \\
TOTAL & 24334.456 & 339 & 71.783 & & \\
\hline
\end{tabular}

Significant at sig of $\mathrm{F}<.05$

The data presented in Table 4 shows that the F-value for group is 2426.121 with significance of $\mathrm{F}$ at .000 , which is less than .05 . The null-hypothesis is therefore rejected at 
0.05 level of significance. With this result, there is significant difference between the mean scores of students taught Building Technology with constructivist instructional approach and those taught using conventional teaching method in cognitive achievement test.

\section{Findings}

The following findings emerged from the stud based on the data collected and analyzed:

1. Students taught Building technology with constructivist instructional approach had a higher mean cognitive achievement score than those students taught using the conventional teaching methods.

2. Students taught Building technology with the constructivist instructional approach had a higher mean psychomotor achievement score than those taught using the conventional leaching methods

3. Boys taught Building technology with the constructivist instructional approach had a higher mean cognitive achievement score than girls taught with the same constructivist instructional approach.

\section{Discussion of Findings}

The data presented in Table 1 provided answer to research question one, finding revealed that students taught with constructivist instructional approach had a higher mean score than those students taught using the conventional teaching method in cognitive achievement test. In the same vein, the analysis of covariance presented in Table 4 confirmed that (lie difference between the mean scores of students taught with constructivist instructional approach and conventional teaching method was significant. The significant difference is attributed to the treatment given to the experimental group. This finding indicated that the constructivist instructional approach has a positive effect on students cognitive achievement in Building Technology. This implies that the constructivist instructional approach (collaborativelearning, oral discourse, thinking skill, authentic task and learning frame) is more effective than the conventional teaching method in enhancing students' cognitive achievement in Building Technology. The findings shows that constructivist instructional approach has positive effect on students achievement is similar to the finding of Epistien and Ryan (2002), who in (her study found out that the adoption of constructivist instructional approach in the teaching of building technology students improved the students' achievement in electronics than the students taught with traditional instructional method.

The data presented in Table 2 provided answer to research question two. Finding revealed that students taught with constructivist instructional approach had a higher mean score than those taught with the conventional teaching method in the test for retention of learning.

The analysis of covariance of the retention test presented in Table 1 confirmed that the difference in the mean score of the students taught with the constructivist instructional approach and those taught with conventional teaching method is significant. This showed that the constructivist instructional approach have positive effect on the students retention of learning in Building technology. These findings stemmed from the fact that constructivist instructional approach enhances hands-on activities which places learning in the hands of the students. The provision of active 
learning environment where students can be engaged and participate actively in class discussions increase the students' ability to explore issues and articulate their own ideas. Also, the use of open ended questions by the teacher makes the students to engage in high thinking task such as analysis, synthesis and evaluation. These consequently improve students' cognitive achievement and also retention. This affirms Boyle, Duffy and Donleavy (2003) views that active learning approach facilitate active knowledge construction, develops high thinking skills, improves memory and enhance transfer of learning to other situation. Rasbult (2005) was of the opinion that by teaching students to think, they will gradually begin to realize that conscious reflection secretes understanding. He maintained that when students learn to think, they will be able to solve all sort of new problem creatively and will have acquired some confidence.

In any educational practices, when students work or learn in groups collaboratively using real object, each person, in order to be an effective participant, will need to think critically in order to make logical contributions. Moreover, when students learn in groups, the good ones always help the average ones to understand the subject matter being learnt. This affirms Epistien and Ryan (2002) view that collaborative learning enhances critical thinking skills and hence, cognitive achievement and retention of learning.

The analysis of the result of the psychomotor achievement test presented in Table 3 which provided answer to research question three showed that students taught with constructivist instructional approach had a higher mean score than those students taught using the conventional teaching method in psychomotor achievement test, The analysis of covariance presented in Table 2 confirmed that the difference between mean score of the students in both groups was significant. These findings indicated that the constructivist instructional approach has a positive effect on technical college students psychomotor achievement in Building technology. This finding may be attributed to the fact that those students taught with constructivist instructional approach engaged in an authentic task in an authentic environment using real objects such as tools and machines. There has been a great deal written about authentic activities in recent times as the influences of constructivist philosophy. According to Rasbult (2005) authentic activities is anything that students are expected to do, beyond getting input through reading or listening, in order to learn, practice, apply, evaluate, or in any other way respond to curricular content' Similarly, Avvalua-efebo (2002) stated that authentic activities 'encourage and affirm learning but essentially, they encourage the learner to respond to the classroom teaching and learning rather than remain passive.

The analysis of covariance between the mean scores of boys and girls in the cognitive achievement test presented on Table 3 showed that the null hypothesis was accepted. This means that there was no significant difference between the mean score of boys and girls in (the experimental group taught with the constructivist instructional approach. Although, the mean score of boys was found to be higher than that of the girls as shown in Table 3, but the difference was not high enough lo be significant. Similarly, the analysis of covariance of the mean score of boys and girls in the psychomotor achievement test, presented in Table 3 showed that there was no significant difference between the mean scores of boys and girls inthe experimental group taught with the constructivist, instructional approach in the psychomotor achievement test. Although, the mean score of boys was higher than the mean score of girls as shown in Table 3, but the difference was not significant. The superiority of the mean score of boys over that of girls in both the cognitive achievement lest and the psychomotor achievement test could 
be explained by the fact that boys are naturally better and more interested in technical subjects than girls since these subjects require more muscle power and alot of activities.

The analysis of covariance of the mean score of boys and girls in the test for retention of learning, presented in Table 4 showed that the null hypothesis was accepted. This implies that there was no significant difference between the mean scores of boys and girls in the experimental group taught with constructivist instructional approach in the test for retention of learning. Although, the mean score of girls was slightly higher than the mean score of boys as shown in Table 4, but the difference was not significant.

\section{Conclusions}

This study set out to determine the effects of the constructivist instructional approach 1 on the achievement of Building technology students in Technical Colleges. The constructivist instructional approach (collaborative learning, oral discourse, thinking skill, authentic task and Framing) used in this study greatly affected the students learning of Building technology. This was reflected in the students' cognitive and psychomotor achievement of learning. In other words, students learnt Building technology and acquired psychomotor skills better when they were allowed to participate actively in the classroom teaching and learning by interacting with teacher, learning environment and their colleagues, work and learn together in groups. Also, students retained their learning for a longer time when they were allowed to think on possible solutions to a problem while engaging in practical activities with real objects, tools and machines collaboratively. It is hoped therefore, that if the constructivist instructional approach is taken into consideration in the teaching of Building technology in the Technical Colleges, craftsmen trained will graduate from the Technical Colleges with knowledge, psychomotor skills, strong problem solving, creative thinking, collaborative work, and independent decision making skills which will make them adaptable to the present and envisaged changes in the automobile industries occasioned by technological advancement. Consequently, the craftsmen will be able to improve on their learning and pass their NABTEB examinations with better grades, contribute their own quota to industrial development of this nation, and become employers of labour instead of hoping solely on paid employment.

\section{Recommendations}

Based on the findings of this study, the following recommendations are made;

1. Technical College teachers should adopt the use of the constructivist Instructional approach to the teaching of Building technology.

2. National Board for Technical Education (NBTE) should consider review of curriculum for Motor vehicle mechanics work programme with a view to incorporating the constructivist instructional approach into the teaching of Building technology.

3. Government should provide tools and equipment needed to teach the slate- of- the art of Building technology in the Technical Colleges. 


\section{References}

Avvolua-efebo, E. B. (2002). Effective teaching principles and practice. Port-Harcourt, Paragraphic.

Boyle, E. A. ; Duffy, T, \& Dunlcavy, K. (2003). Learning styles and academic outcome: The validity and utility of vermants inventory of learning style in a British higher education selling. British Journal of Educational Psychology. 73 (2): 267290.

Cleminson, A. (2000). Establishing an epislcmologica! base for science leaching in the light of contemporary notions of the nature of science and of how children learn science. Journal of Research Science Teaching. 27(5): 429-446.

Demmert, K. L. (2001). Improving academic performance among native American students: A Review of the Research Literature. Retrieved March 20,2006 from htlp://www. aor. com/pdf

Epistein, M., \& Ryan, I. (2002). Constructivist. Retrieved March 18, 2004, from http/f: www.scholar/lib. vt.odu/ejournals/jje/jte-v 7ni/epistein.jte-vl 9nl.htm

Federal Ministry of Education (2000). Technical and vocational education Development in Nigeria in the $2 /{ }^{\prime w}$ century with the blue-print 'for the Decade 2001 $\sim 2010$.

Federal Ministry of Education (2001), 7Jie National Master-plan for Technical and Vocational Development in Nigeria in the $21^{\text {st }}$ Century with the Blue Print for the Decade 2010, Abuja, FME.

Rasbult, C. (2005). Thinking skills in education: comparing for frameworks. . Retrieved April 2 1, 2006 from http//:www.accd.edu/spc/master/adjunctminithinkingskiUs.pdf

Rojevvski, W. J. (2002). Preparing the workforce of tomorrow: a conceptual framework for career and technical education.Journal of Vocational Education Research. Retrieved March, 2006 from http://www.scholor.lib.vt.edU/ejourmls/JUER/v27nl/rojewski:hlml 